\title{
Does How Caffeine Can Increase Thyroid Hormone Levels?
}

\author{
Luiz Augusto da Silva* \\ Department of Physical Education, Faculdade Guairacá, Brazil \\ *Corresponding author: Luiz Augusto da Silva, Department of Physical Education, Faculdade Guairacá, Guarapuava, Paraná, Brazil
}

Submission: 悳 May 10, 2018; Published: 監 May 18, 2018

\section{Opinion}

The energy balance is stimulated by hormonal concentrations, physical exercise and diet. Thus, the amount of circulating thyroid hormones $(\mathrm{TH})$ in the bloodstream directly influences the energy balance. Caffeine and exercise have the effect of increasing TH concentrations, increasing the action of these hormones and consequently the energy balance. In addition, the reduction of physical exercise reduces TH values, leading to a reduction in the energy balance. The caffeine ingestion changed the metabolic homeostasis, there is a reduction of $\mathrm{TH}$ concentration, triggering a balance in the influx of cellular substrates and perhaps, a greater catalytic action of the energetic substrates, in tissues such as the skeletal muscle and adipose tissue, as well as, a production and liberation of energy by the cell, due to the increased concentration of intracellular $\mathrm{Ca}^{2+}$ caused by caffeine [1]

Some studies have reported in animals that $\mathrm{TH}$ regulates the transcription of various genes expressed in skeletal muscle, such as type I myosin heavy-chain (MHC), act in and sacoplasmic reticulum (SR) $\mathrm{Ca}^{2+}$ ATPase pump [2,3]. In addition, hypothyroidism and hyperthyroidism may, respectively, reduce and increase uptake of $\mathrm{Ca}^{2+}$ by SR [4]. As results of TH effects on MHC expression and $\mathrm{Ca}^{2+}$ uptake, the reduction in skeletal muscle shortening speed increases with increased TH levels [5]. Still, slow fibers exhibit greater sensitivity to TH than fast ones. With physiological limits, increased activity of TH may be associated with an increased efficiency of mechanical workout by muscles during training [6]. It is known that high doses of caffeine $(200 \mathrm{mg} / \mathrm{kg})$ may affect the secretion of several hormones, and in short-term experiments (1week) a reduction in TSH secretion was shown after a daily caffeine intake [7]. Bartsch et al. [8] aimed to elucidate the effect of a sub-chronical consumption of caffeine over thyroid (per 90 days-104mg/kg/ day). This study demonstrated an increase of body weight to the animals that consumed caffeine, however, no alterations occurred in $\mathrm{T}_{3}$ and $\mathrm{T}_{4}$ levels, adrenal weight, histopathology of thyroid on the $21^{\text {st }}$ and $90^{\text {th }}$ day. Spindel et al. [9] showed that caffeine may reduce TSH and GH concentration in a dosage of $50 \mathrm{mg} / \mathrm{Kg}$. The reduction of TSH was followed by a $\mathrm{T}_{3}$ and $\mathrm{T}_{4}$ reduction after $4 \mathrm{~h}$ of caffeine administration. In vitro, caffeine did not alter significantly the hormonal secretion of pituitary cells.

THs being used during exercise are described in the literature for a few decades. Analysis of TH levels of professional cyclists during 3 weeks of competition showed that $\mathrm{T}_{4}, \mathrm{~T}_{3}$ levels increased significantly in the last week of competition and TSH concentrations did not change [10]. This shows that the influence of exercise to control the energy balance is fundamental for weight control and also for performance. The non-alteration in TSH levels may be influenced by the slight alteration in $\mathrm{T}_{3}$ and $\mathrm{T}_{4}$ levels presented, since other studies show changes in TSH at greater intensities of exercise. Huang et al. [11] showed changes in $\mathrm{T}_{3}$ and $\mathrm{T}_{4}$ levels during an exercise session. According to the author, the possible cause of increased TSH levels may be due to secretion of the pituitary serving as a fill of the increased use of peripheral TH induced by exercise [12].

Exercise intensity also appears to affect the mechanism of TH release. Increased metabolic activity through physical training on $\mathrm{TH}$ is related to exercise intensity and which hormones are most severely affected. When an increase in intensity occurs, ranging from 45 to $70 \%$, all $\mathrm{TH}$, except for $\mathrm{TSH}$, increase, close to the anaerobic threshold (70\% HRmax). Thus, the caffeine associated or not to exercise has a direct influence on the concentrations of TH, leading to important effects on the energy balance and consequently on the physical performance control and stocking of substrates.

\section{References}

1. Silva LA (2017) Relation between diabsetes mellitus, thyroid hormones and caffeine. J Appl Pharm Sci 7(3): 212-216.

2. Sasaki S (2018) The mechanism of negative transcriptional regulation by thyroid hormone: lessons from the thyrotropin $\beta$ subunit gene. Vitam Horm 106(2): 97-127.

3. Senese R (2017) Both 3, 5-Diiodo-L-Thyronine and 3, 5, 3'-Triiodo-L-Thyronine prevent short-term hepatic lipid accumulation via distinct mechanisms in rats being fed a high-fat diet. Front Physiol 8(1): 1-9. 
4. Baldwin KM (2013) Alterations in muscle mass and contractile phenotype in response to unloading models: role of transcriptional/pretranslational mechanisms. Front Physiol 4(2): 284-297.

5. Salvatore D, Simonides WS, Dentice M, Zavacki AM, Larsen PR (2014) Thyroid hormones and skeletal muscle-new insights and potential implications. Nat Rev Endocrinol 10(4): 206-215.

6. Gullu S, Altuntas F, Dincer I, Erol C, Kamel N (2004) Effects of TSH-suppressive therapy on cardiac morphology and function: beneficial effects of the addition of beta-blockade on diastolic dysfunction. Eur J Endocrinol 150(2): 655-661.

7. Spindel ER, Griffith L, Wurtman RJ (1983) Neuroendocrine effects of caffeine. II. Effects on thyrotropin and corticosterone secretion. J Pharmacol Exp Ther 225(3): 346-350.

8. Bartsch W, Dasenbrock C, Ernst H, Kamino K, Mohr U (1996) Absence of effect of caffeine on the thyroid in the syrian golden hamster results of a 90-day study. Food Chem Toxicol 34(2): 153-159.
9. Spindel ER, Wurtman RJ (1984) Neuroendocrine effects of caffeine in rat and man. In: Dews PB (Ed.), Caffeine, Perspectives from Recent Research. Springer-Verlag, Berlin, Germany.

10. Koistinen P, Martikkala V, Karpakka J, Vuoiteenaho O, Leppaluoto J (1996) The effects of moderate altitude on circulating thyroid hormones and thyrotropin in training athletes. J Sports Med Phys Fitness 36(3): 408-411.

11. Huang WS, Yu MD, Lee MS, Cheng CY, Yang SP, et al. (2004) Effect of treadmill exercise on circulating thyroid hormone measurements. Med Princ Pract 13(2): 15-19.

12. Ciloglu F, Peker I, Pehlivan A, Karacabey K, Ilhan N, et al. (2005) Exercise intensity and its effects on thyroid hormones. Send to Neuro Endocrinol Lett 26(6): 830-834.

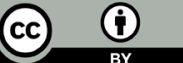

Creative Commons Attribution 4.0 International License

For possible submissions Click Here

\section{Submit Article}

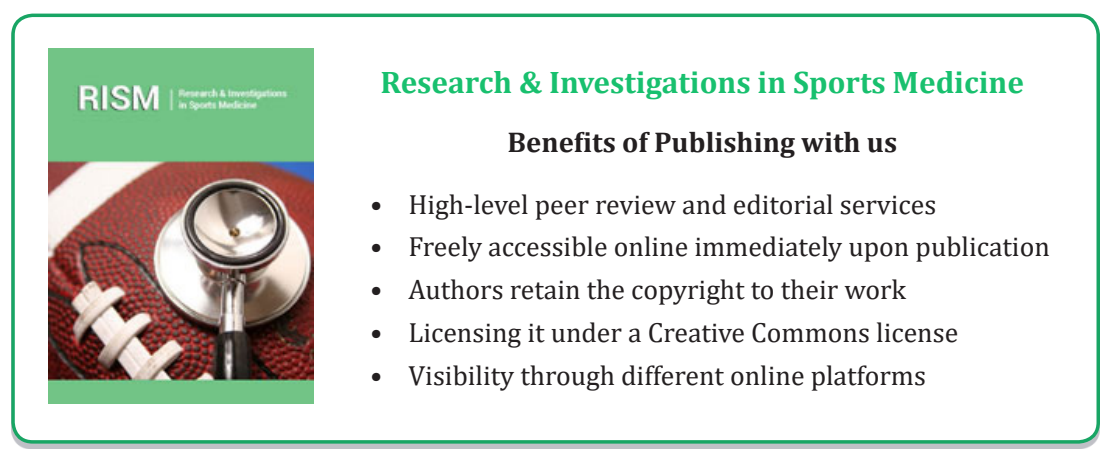

